\title{
A Smart Magnetic Resonance Contrast Agent for Selective Copper Sensing
}

\author{
Emily L. Que and Christopher J. Chang* \\ Department of Chemistry, University of California, Berkeley, CA 94720
}

Synthetic Materials and Methods. Column chromatography was performed using SiliaFlash P60 silica gel (40-63 microns) from Silicycle (Quebec, Canada). Analytical thin layer chromatography was performed using glass-backed TLC plates $(250 \mu \mathrm{m}$ thick) from Silicycle. Chemicals were purchased from Sigma-Aldrich (St. Louis, MO), Acros Organics (Morris Plains, NJ), and Strem (Newburyport, MA) and were used as received. Dulbecco's Phosphate Buffered Saline (PBS) was purchased from Invitrogen (Carlsbad, CA). NMR spectra were obtained in deuterated solvents from Cambridge Isotope Laboratories (Cambridge, MA) on a Bruker AV300 or AV-400 spectrometer at the College of Chemistry NMR Facility at the University of California, Berkeley. All chemical shifts are reported in the standard $\delta$ notation of parts per million using the peak of residual proton and carbon signals of the solvent as internal reference. High-resolution fast atom bombardment (FAB) mass spectral analyses were performed by the College of Chemistry Mass Spectrometry Facility at the University of California, Berkeley. High resolution Electrospray Ionization (ESI) mass spectral analyses were performed by the Mass Spectrometry Laboratory at the University of Illinois, Urbana-Champaign. Inductively coupled plasma optical emission spectrometry (ICP-OES) was performed on a Perkin Elmer Optima 5300 DV ICP-OES in the College of Natural Resources Inductively Coupled Plasma Facility at the University of California, Berkeley.

3-(2-Nitrophenoxy)propan-1-ol (1). 2-Nitrophenol (10.0 g, 71.9 mmol) and $\mathrm{NaOH}$ (2.88 g, 72.0 mmol) were combined in dry DMF $(80 \mathrm{~mL})$ and the resulting mixture was heated at $80{ }^{\circ} \mathrm{C}$ under a nitrogen atmosphere for 3.5 hours. Next, 3-bromopropanol $(6.50 \mathrm{~mL}, 71.9 \mathrm{mmol})$ was added and the reaction was heated at $80^{\circ} \mathrm{C}$ under nitrogen overnight. The mixture was cooled to room temperature and water $(100 \mathrm{~mL})$ was added. The reaction was then extracted with ethyl acetate and the organic layer was separated, dried over $\mathrm{Na}_{2} \mathrm{SO}_{4}$, and concentrated to give a yellow oil. Purification by flash column chromatography (silica gel, 1:1 hexanes/ethyl acetate) afforded pure 1 as a pale yellow oil $\left(10.2 \mathrm{~g}, 72 \%\right.$ yield). ${ }^{1} \mathrm{H}$ NMR $\left(300 \mathrm{MHz}, \mathrm{CDCl}_{3}, 25^{\circ} \mathrm{C}\right): \delta 7.84(1 \mathrm{H}, \mathrm{dd}, J$ = 1.6, $8.3 \mathrm{~Hz}), 7.53(1 \mathrm{H}, \mathrm{td}, J=1.6,7.9 \mathrm{~Hz}), 7.10(1 \mathrm{H}, \mathrm{dd}, J=0.9,8.3 \mathrm{~Hz}), 7.02(1 \mathrm{H}, \mathrm{td}, J=0.9$, $7.9 \mathrm{~Hz}$ ), 4.27 (t, $2 \mathrm{H}, J=5.6 \mathrm{~Hz}$ ), $3.89\left(\mathrm{t}, 2 \mathrm{H}, J=5.6 \mathrm{~Hz}\right.$ ), 2.11 (quintet, $2 \mathrm{H}, J=5.6 \mathrm{~Hz}$ ). ${ }^{13} \mathrm{C}$ NMR (75 MHz, $\left.\mathrm{CDCl}_{3}, 25^{\circ} \mathrm{C}\right): \delta 152.50,139.58,134.63,126.08,120.55,114.34,67.79,60.40$, 31.70. HRFAB-MS: calculated for $\left[\mathrm{C}_{9} \mathrm{H}_{12} \mathrm{NO}_{4}\right]^{+} 198.0766$, found 198.0764 .

3-(2-Aminophenoxy)propan-1-ol (2). To a solution of 1 (5.0 g, $25.3 \mathrm{mmol})$ in ethanol (50 mL) and ethyl acetate $(25 \mathrm{~mL})$ was added $10 \% \mathrm{Pd} / \mathrm{C}(500 \mathrm{mg})$. The resulting mixture was stirred at room temperature under $1 \mathrm{~atm}$ of $\mathrm{H}_{2}$ for 2 days. The reaction was then filtered over celite to remove the palladium catalyst and the solvents were removed by rotary evaporation to furnish pure 2 as a colorless oil $\left(4.23 \mathrm{~g}, 100 \%\right.$ yield). ${ }^{1} \mathrm{H} \mathrm{NMR}\left(300 \mathrm{MHz}, \mathrm{CDCl}_{3}, 25^{\circ} \mathrm{C}\right): \delta 6.69-6.83$ $(4 \mathrm{H}, \mathrm{m}), 4.14(2 \mathrm{H}, \mathrm{t}, J=6 \mathrm{~Hz}), 3.87(2 \mathrm{H}, \mathrm{t}, J=6 \mathrm{~Hz}), 2.87$ (br, 2H), 2.06 (2H, quint, $J=6 \mathrm{~Hz})$. ${ }^{13} \mathrm{C}$ NMR $\left(75 \mathrm{MHz}, \mathrm{CDCl}_{3}, 25{ }^{\circ} \mathrm{C}\right): \delta 146.65,136.33,121.49,119.78,115.42,113.96,65.90$, 60.37, 32.30. HRFAB-MS: calculated for $\left[\mathrm{C}_{9} \mathrm{H}_{13} \mathrm{NO}_{2}\right]^{+}$167.0946, found 167.0948.

Diethyl 2,2'-(2-(3-hydroxypropoxy)phenylazanediyl)diethanoate (3). Amino compound 2 (4.23 g, $25.3 \mathrm{mmol})$, ethyl bromoacetate $(8.4 \mathrm{~mL}, 75.9 \mathrm{mmol})$, NaI (7.65 g, $51.0 \mathrm{mmol}), N, N$ - 
diisopropylethylamine (DIEA, $11 \mathrm{~mL}, 63.2 \mathrm{mmol}$ ), and DMF (30 mL) were combined in an oven-dried Schlenk flask. The resulting mixture was heated under a nitrogen atmosphere for $18 \mathrm{~h}$ at $100{ }^{\circ} \mathrm{C}$, at which point additional portions of ethyl bromoacetate $(2.8 \mathrm{~mL}, 25.3 \mathrm{mmol})$ and DIEA (4.4 mL, $25.3 \mathrm{mmol}$ ) were added. The reaction was heated for an additional $12 \mathrm{~h}$, cooled to room temperature, and the solvent was removed by rotary evaporation. Purification by flash column chromatography (silica gel, 10:1 to 1:1 hexanes/ethyl acetate) delivered pure 3 as a tancolored solid (7.52 g, 87\% yield). ${ }^{1} \mathrm{H}$ NMR (400 MHz, $\left.\mathrm{CDCl}_{3}, 25^{\circ} \mathrm{C}\right): \delta 6.90-6.80(4 \mathrm{H}, \mathrm{m}), 4.15-$ $4.07(10 \mathrm{H}, \mathrm{m}), 3.77(2 \mathrm{H}, \mathrm{t}, J=5.8 \mathrm{~Hz}), 1.96(2 \mathrm{H}, \mathrm{q}, J=5.8 \mathrm{~Hz}), 1.21(6 \mathrm{H}, \mathrm{t}, J=7.2 \mathrm{~Hz}) .{ }^{13} \mathrm{C}$ NMR (100 MHz, $\left.\mathrm{CDCl}_{3}, 25{ }^{\circ} \mathrm{C}\right): \delta 171.60,151.14,139.21,122.83,121.28,120.09,113.66$, 66.77, 60.77, 60.21, 53.82, 32.03, 14.26. HRFAB-MS: calculated for $\left[\mathrm{C}_{17} \mathrm{H}_{25} \mathrm{NO}_{6}\right]^{+} 339.1682$, found 339.1690.

Diethyl 2,2'-(2-(3-bromopropoxy)phenylazanediyl)diethanoate (4). Under a nitrogen atmosphere, triphenylphosphine (3.65 g, $13.9 \mathrm{mmol})$ and 3 (2.37 g, $6.98 \mathrm{mmol})$ were combined in dry dichloromethane $(175 \mathrm{~mL})$ and the resulting solution was cooled to $0^{\circ} \mathrm{C}$. Under exclusion of light, carbon tetrabromide $(4.69 \mathrm{~g}, 14.1 \mathrm{mmol})$ was added and the reaction was stirred at $0{ }^{\circ} \mathrm{C}$ for $3 \mathrm{~h}$. The contents were directly loaded onto a silica gel column and purification by flash column chromatography (10:1 hexanes/ethyl acetate) gave 4 as a light yellow oil (2.35 g, 84\% yield). ${ }^{1} \mathrm{H}$ NMR (300 MHz, $\left.\mathrm{CDCl}_{3}, 25^{\circ} \mathrm{C}\right): \delta 6.92-6.79(4 \mathrm{H}, \mathrm{m}), 4.18(4 \mathrm{H}, \mathrm{q}, J=7.2 \mathrm{~Hz}), 4.12$ $(4 \mathrm{H}, \mathrm{s}), 4.10(2 \mathrm{H}, \mathrm{t}, J=6.3 \mathrm{~Hz}), 3.56(2 \mathrm{H}, \mathrm{t}, J=6.3 \mathrm{~Hz}), 2.28(2 \mathrm{H}$, quint, $J=6.3 \mathrm{~Hz}), 1.26(6 \mathrm{H}$, t, $J=7.2 \mathrm{~Hz}$ ). ${ }^{13} \mathrm{C}$ NMR (75 $\left.\mathrm{MHz}, \mathrm{CDCl}_{3}, 2{ }^{\circ} \mathrm{C}\right): \delta 171.16,150.47,139.36,122.40,121.51$, 119.33, 113.53, 66.55, 60.82, 53.71. 32.59, 30.23, 14.35. HRFAB-MS: calculated for $\left[\mathrm{C}_{17} \mathrm{H}_{24} \mathrm{BrNO}_{5}\right]^{+}$401.0837, found 401.0834.

Diethyl 2,2'-(2-(3-(1,4,7,10-tetraazacyclododecan-1-yl)propoxy)phenylazanediyl) diethanoate (5). Under a nitrogen atmosphere, cyclen (2.53 g, $14.7 \mathrm{mmol})$ was added to $15 \mathrm{~mL}$ chloroform that was previously passed through neutral alumina. A solution of bromide 4 (2.35 g, $5.84 \mathrm{mmol}$ ) in chloroform $(5 \mathrm{~mL})$ was added dropwise to the cyclen solution, and the reaction was stirred for 2 days at room temperature under nitrogen. Removal of the solvent and purification by flash column chromatography (silica gel, gradient from 10:1 chloroform/methanol to remove non-polar by-products to $8: 2: 1$ chloroform/methanol/conc aq $\mathrm{NH}_{4} \mathrm{OH}$ for product elution) to yield 5 as a viscous yellow oil (2.44 g, 85\% yield). ${ }^{1} \mathrm{H}$ NMR (300 MHz, MeOD, 25ㅇ): $\delta$ 7.05-6.79 (4H, m), $4.06(4 \mathrm{H}, \mathrm{q}, J=7.2 \mathrm{~Hz}), 4.02(4 \mathrm{H}, \mathrm{s}), 3.96(2 \mathrm{H}, \mathrm{t}, J$ $=6.2 \mathrm{~Hz}), 2.65-2.41(18 \mathrm{H}, \mathrm{m}), 1.93(2 \mathrm{H}, \mathrm{q}, J=6.2 \mathrm{~Hz}), 1.15(6 \mathrm{H}, \mathrm{t}, J=7.2 \mathrm{~Hz}) .{ }^{13} \mathrm{C}$ NMR $(75$ $\left.\mathrm{MHz}, \mathrm{MeOD}, 25^{\circ} \mathrm{C}\right): \delta 172.06,150.965,139.29,122.20,120.92,119.05,113.56,66.65,60.645$, 53.70, 51.09, 50.66, 46.10, 45.46, 44.17, 27.10, 13.42. HRFAB-MS: calculated for $\left[\mathrm{C}_{25} \mathrm{H}_{44} \mathrm{~N}_{5} \mathrm{O}_{5}\right]^{+}$494.3342, found 494.3328.

\section{2,2',2"'-(10-(3-(2-(Bis(carboxymethyl)amino)phenoxy)propyl)-1,4,7,10-tetraaza-}

cyclododecane-1,4,7-triyl)triethanoic acid (6). Bromoacetic acid (318 mg, $2.29 \mathrm{mmol}$ ) was added to an aqueous solution of 5 (159 $\mathrm{mg}, 0.318 \mathrm{mmol})$, and the mixture was brought to $\mathrm{pH} 14$ with the addition of $1 \mathrm{M}$ aq $\mathrm{NaOH}$. The mixture was heated at $45^{\circ} \mathrm{C}$ and the $\mathrm{pH}$ was measured periodically and adjusted back to $\mathrm{pH} 14$ with additional $1 \mathrm{M}$ aq $\mathrm{NaOH}$ when needed. When the $\mathrm{pH}$ stabilized, the flask contents were cooled to room temperature and lyophilized to a white solid. Purification on a Sephadex LH-20 size-exclusion column using water as an eluant produced pure 6 as a white solid (151 mg, 65\% yield). ${ }^{1} \mathrm{H}$ NMR (300 MHz, MeOD, 25 ${ }^{\circ} \mathrm{C}$ ): $\delta$ $7.07(1 \mathrm{H}, \mathrm{m}), 6.95(2 \mathrm{H}, \mathrm{m}), 6.85(1 \mathrm{H}, \mathrm{m}), 4.03(2 \mathrm{H}, \mathrm{m}), 3.85(2 \mathrm{H}, \mathrm{s}), 3.56(4 \mathrm{H}, \mathrm{s}), 3.30-1.80$ $(22 \mathrm{H}, \mathrm{m}), 2.08(2 \mathrm{H}, \mathrm{m})$. HRESI-MS: calculated for $\left[\mathrm{C}_{27} \mathrm{H}_{42} \mathrm{~N}_{5} \mathrm{O}_{11}\right]^{+}$612.2881, found 612.2894. 
Copper-Gad-1 (CG1, 7). Ligand 6 (53 mg, $0.087 \mathrm{mmol}$ ) and $\mathrm{GdCl}_{3} \bullet 6 \mathrm{H}_{2} \mathrm{O}(50 \mathrm{mg}, 0.13 \mathrm{mmol})$ were combined in water $(3 \mathrm{~mL})$. The $\mathrm{pH}$ was adjusted to 7 with added portions of dilute aq $\mathrm{NaOH}$ or $\mathrm{HCl}$ and the reaction was stirred at room temperature overnight, maintaining the solution at $\mathrm{pH} 7$ with added portions of $\mathrm{NaOH}$. The solvent was removed by lyophilization and purification on a Sephadex LH-20 size-exclusion column using water as an eluant afforded pure 7 as a white solid (65 mg, 80\% yield). Gd content was measured using ICP-OES. HRESI-MS: calculated for $\left[\mathrm{C}_{27} \mathrm{H}_{39}{ }^{155} \mathrm{GdN}_{5} \mathrm{O}_{11}\right]^{+}$764.1873, found 764.1872. The appropriate isotope distribution was observed for $\mathrm{Gd}$. The corresponding $\mathrm{Tb}^{3+}$ and $\mathrm{Lu}^{3+}$ complexes of $\mathbf{6}$ were synthesized in an analogous manner (LRESI-MS: calculated for Tb complex $\left[\mathrm{C}_{27} \mathrm{H}_{37} \mathrm{TbN}_{5} \mathrm{O}_{11}\right]^{-}$ 766.2, found 766.5; calculated for Lu complex $\left[\mathrm{C}_{27} \mathrm{H}_{37} \mathrm{LuN}_{5} \mathrm{O}_{11}\right]^{-}$782.2, found 782.1).

Spectroscopic Measurements. All $\mathrm{T}_{1}$ values were measured with a Bruker Avance 400 NMR spectrometer using a modified inversion-recovery procedure with a $2 \%$ gradient pulse. The $90^{\circ}$ pulse was calibrated for each sample individually. Samples were measured in a $60 \mu \mathrm{L}$ NMR tube coaxial insert (Wilmad glass) within a $5 \mathrm{~mm}$ NMR tube containing $\mathrm{d}_{6}$-DMSO. All NMR samples were prepared in PBS buffer, $\mathrm{pH}$ 7.4. Gd concentrations were determined using ICP-OES and the relaxivity of CG1 was determined from the slope of the plot of $1 / T_{1}$ vs. [CG1]. The apparent $K_{\mathrm{d}}$ was determined from a plot of relaxivity vs $\left[\mathrm{Cu}^{2+}\right]$. The data were fitted to the following equation: $\mathrm{R}_{1}=\left(\mathrm{R}_{1 \max }\left[\mathrm{Cu}^{2+}\right]+\mathrm{R}_{1 \min } \mathrm{K}_{\mathrm{d}}\right) /\left(\mathrm{K}_{\mathrm{d}}+\left[\mathrm{Cu}^{2+}\right]\right)$, where $\mathrm{R}_{1}$ is the observed relaxivity, $\mathrm{R}_{1 \max }$ is the maximum relaxivity and $\mathrm{R}_{1 \min }$ is the relaxivity of CG1. The Hill coefficient was determined from the slope of the linear least-squares fit of $\log \left[\left(R_{1 \min }-R_{1}\right) /\left(R_{1}-R_{1 \text { max }}\right)\right]$ vs $\log \left[\mathrm{Cu}^{2+}\right] .^{1}$

Luminescence measurements were performed on solutions consisting of $400 \mu \mathrm{M}$ Tb-6 dissolved in PBS (or its $\mathrm{D}_{2} \mathrm{O}$ equivalent) in the absence or presence of excess $\mathrm{CuSO}_{4}(500 \mu \mathrm{M})$ or $\mathrm{ZnCl}_{2}$ $(500 \mu \mathrm{M})$. Samples were excited at $290 \mathrm{~nm}$ and the emission maximum $(544 \mathrm{~nm})$ was used to determine luminescence lifetimes. The observed data were fitted to a single-exponential decay using least-squares analysis. The number of bound water molecules was estimated using Horrocks' equation: $q=4.2\left(1 / \tau_{\mathrm{H} 2 \mathrm{O}}-1 / \tau_{\mathrm{D} 2 \mathrm{O}}\right)$, where $\tau$ is the luminescence lifetime in $\mathrm{H}_{2} \mathrm{O}$ or $\mathrm{D}_{2} \mathrm{O} .^{2}$

\section{References}

1. Hill, A. V. J. Physiol. (London) 1910, 40, pp IV-VII.

2. Horrocks, W. D., Jr.; Sudnick, D. R. Acc. Chem. Res. 1981, 14, 384-392. 


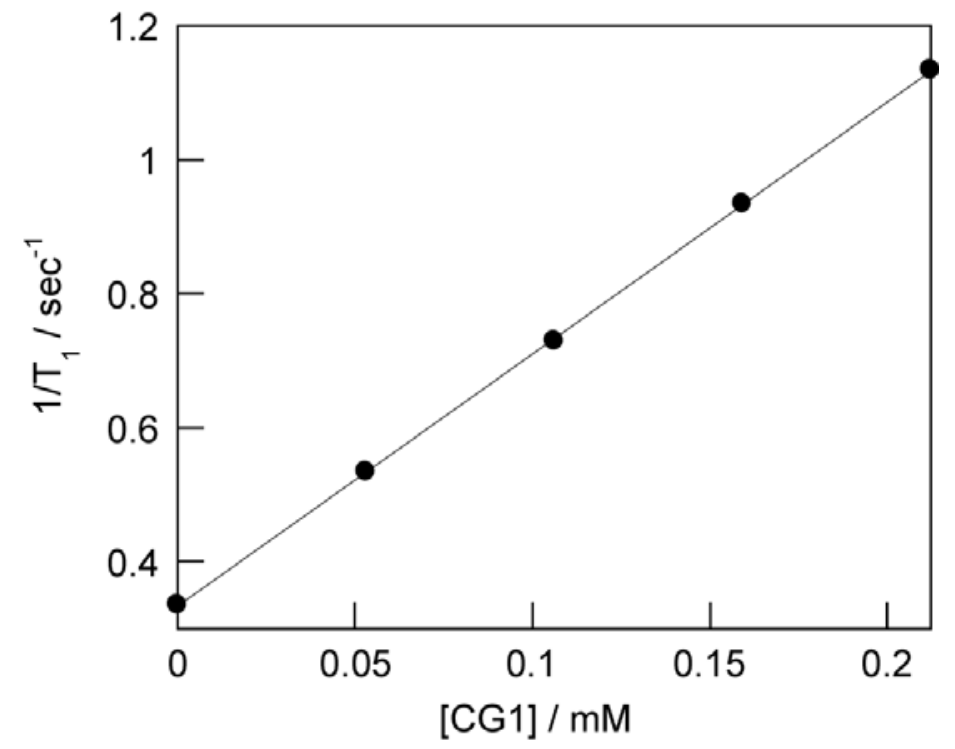

Figure S1. Plot of $1 / T_{1}$ vs. [CG1]. Longitudinal relaxation times $\left(T_{1}\right)$ were acquired in PBS buffer, $\mathrm{pH} 7.4$, at a proton frequency of $400 \mathrm{MHz}$. The points shown correspond to CG1 concentrations of $0,0.05,0.11,0.16$, and $0.21 \mathrm{mM}$.

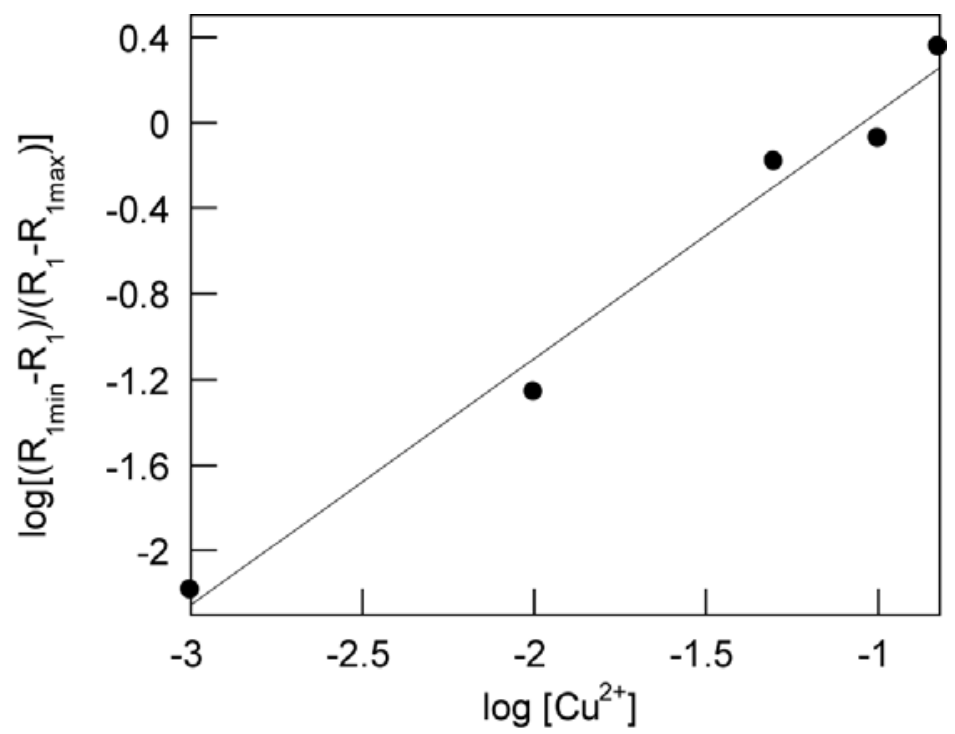

Figure S2. Hill plot of CG1 relaxivity for various $\left[\mathrm{Cu}^{2+}\right]$. Relaxivity measurements were performed in PBS buffer, $\mathrm{pH}$ 7.4, at a proton frequency of $400 \mathrm{MHz}$. The points shown are for added $\mathrm{Cu}^{2+}$ concentrations of $0.001,0.010,0.050,0.100$ and $0.150 \mathrm{mM}$ to a $0.21 \mathrm{mM}$ CG1 solution. 

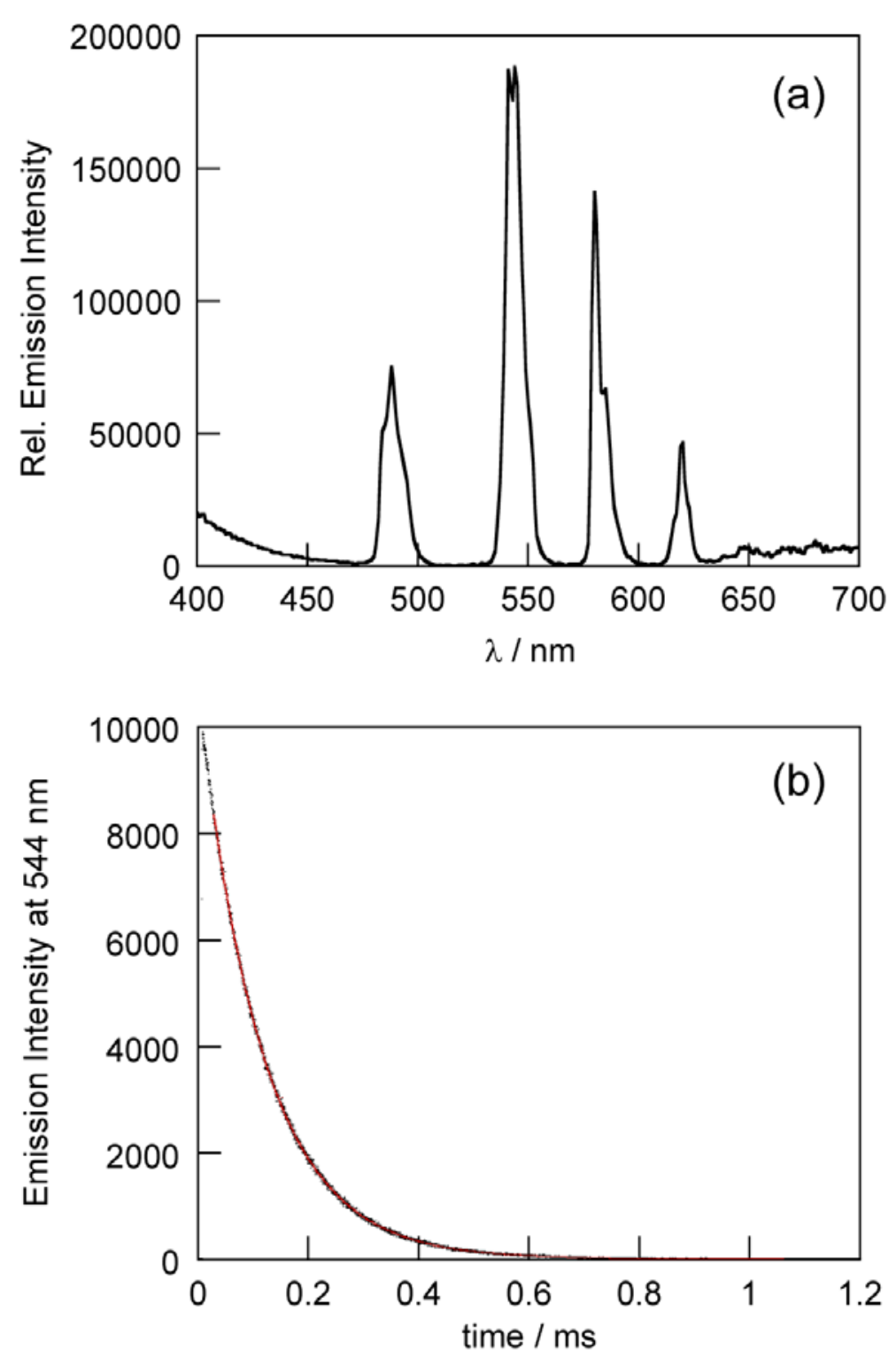

Figure S3. Representative luminescence data for Tb-6. (a) Emission spectrum of $400 \mu \mathrm{M}$ Tb-6 (PBS buffer in $\mathrm{D}_{2} \mathrm{O}$, no $\mathrm{Cu}^{2+}$ added) recorded using an excitation wavelength of $290 \mathrm{~nm}$. (b) Luminescence decay curve data (black trace) and least-squares monoexponential fit (red trace) of Tb-6 (PBS buffer in $\mathrm{D}_{2} \mathrm{O}$, no $\mathrm{Cu}^{2+}$ added). Samples were excited at $290 \mathrm{~nm}$ and emission was collected at $544 \mathrm{~nm}$.

Table S1. Luminescence lifetimes and calculated number of inner-sphere water molecules $(q)$ for the $\mathrm{Tb}^{3+}$ analog of CG1 in the absence and presence of $\mathrm{Cu}^{2+}$ and $\mathrm{Zn}^{2+}$.

\begin{tabular}{cccc}
\hline & $\tau_{\mathrm{H} 2 \mathrm{O}} / \mathrm{ms}$ & $\tau_{\mathrm{D} 2 \mathrm{O}} / \mathrm{ms}$ & $q$ \\
\hline No added $\mathrm{Cu}^{2+}$ & 2.37 & 2.88 & 0.31 \\
$500 \mu \mathrm{M} \mathrm{Cu}^{2+}$ & 1.22 & 1.76 & 1.07 \\
$500 \mu \mathrm{M} \mathrm{Zn}^{2+}$ & 2.26 & 2.76 & 0.34
\end{tabular}


Table S2. Data obtained from ICP measurements on standard solutions of Gd and on a 10-fold diluted solution of CG1. Standard solutions were prepared from a stock solution containing 997 $\mu \mathrm{g} / \mathrm{mL} \mathrm{Gd}$.

\begin{tabular}{cc}
\hline Sample & Emission Intensity/ counts \\
\hline $49.85 \mu \mathrm{g} / \mathrm{mL} \mathrm{Gd}$ & 734678 \\
$9.97 \mu \mathrm{g} / \mathrm{mL} \mathrm{Gd}$ & 152163 \\
$0.997 \mu \mathrm{g} / \mathrm{mL} \mathrm{Gd}$ & 12231 \\
$0.0997 \mu \mathrm{g} / \mathrm{mL} \mathrm{Gd}$ & 1610 \\
$0 \mu \mathrm{g} / \mathrm{mL} \mathrm{Gd}$ & 156 \\
CG1 solution, diluted 10-fold & 49902
\end{tabular}

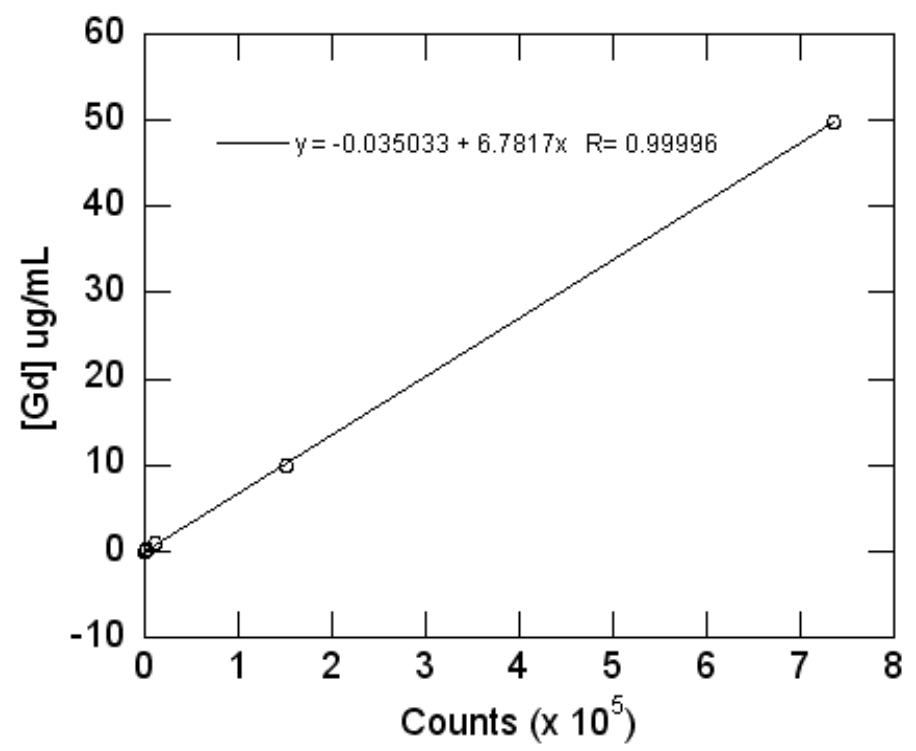

Figure S4. Plot of calibration data obtained from ICP measurements and best fit line.

Calculated concentration of CG1 solution:

$[C G 1] / 10=-0.035033+6.7817(49902)=3.35 \mu \mathrm{g} / \mathrm{mL} \rightarrow$ concentration of original CG1 solution: $0.21 \mathrm{mM}$ 


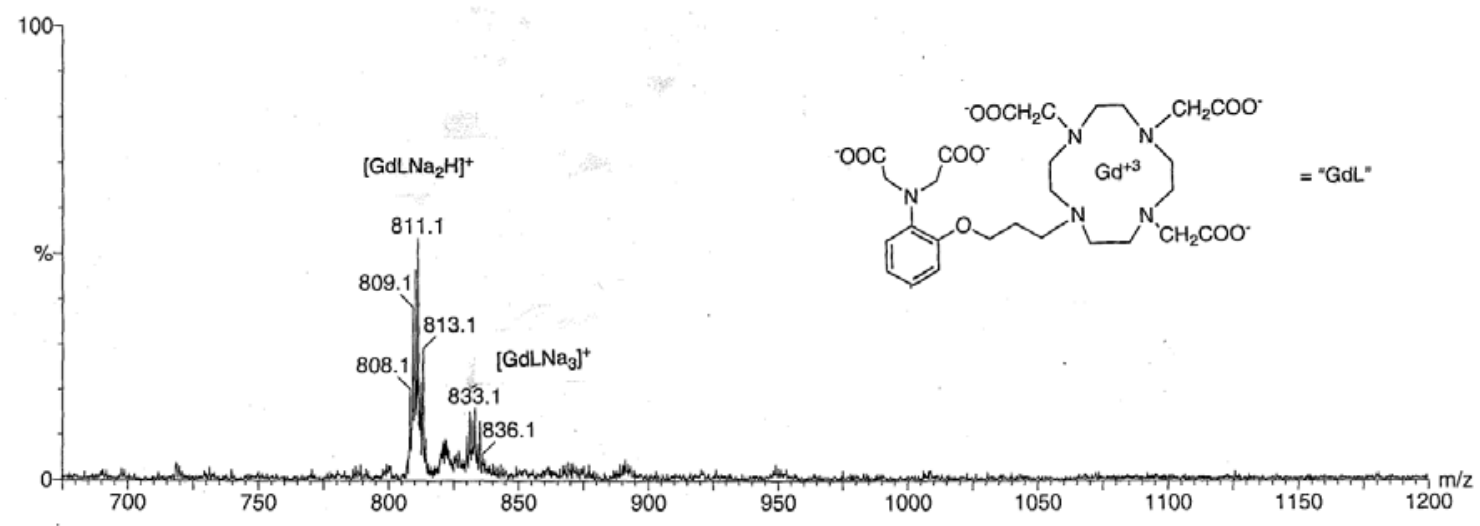

Figure S5. Electrospray mass spectrum of CG1. 